\title{
LAW IN THE PROCESS OF SOCIAL INTEGRATION OF IMMIGRANTS
}

\author{
Georgi MIHAYLOV \\ South-West University "Neofit Rilski”, Blagoevgrad, Bulgaria \\ mihaylov@law.swu.bg
}

\begin{abstract}
The article explores the problem of social integration of immigrants from Asia and Africa, arriving in European countries. Emphasis is placed on cultural differences between the existing society and immigrants that create social tension and conflicts. The solution to the problem should be seen in the implementation of positive law, which is applied in the host country. The main arguments in support of this opinion are the fundamental individual rights and the principle: first in time is first in right.
\end{abstract}

\section{Keywords: legal order, social integration, immigrats, cultural differences and law}

We are contemporaries in a period in which migration processes worldwide are growing and creating challenges for countries and for the individual societies they inhabit. Historically, this phenomenon is not new, it is the cause of military conflicts in which entire peoples and countries have been killed and/or assimilated.

The civilizational development of the modern world organises the secular societies in the form of the rule of law. These are most of the countries located on the European continent, which are targeted by migration waves of people from Asia and Africa. States belonging to the European Union, including Bulgaria, organise and regulate relations among individuals and different ethnic groups through the law.

Law is a social phenomenon whose main function is to regulate social relations and prevent and resolve conflicts in society. The need for this legal effect is particularly pressing in the era of globalisation, when technology overcomes the boundaries of communication and interaction, and military conflicts and climate change inspire migration of millions of people. Fleeing wars and unrest, they are persecuted because of their political or religious views, seeking employment or forced by natural disasters, people migrate and the migration processes in the $21^{\text {st }}$ century have intensified. More and more areas are depopulated as a result of climatic disasters and regional conflicts, causing mass migration and the creation of multicultural states and societies.

The co-existence of many different ethnic groups in a country is a challenge for the institutions and the maintenance of social homeostasis. The problem is legally particularly topical in the generative tendency for the population of the European continent to grow, because of the exodus of millions of people from Asia and Africa. In this situation, law is the institutional instrument that is to homogenise interactions between individuals in an increasingly multicultural society.

The difference between the ethnic groups is due to the diversity of their culture or individual cultural elements. The culture represents "... a combination of 
knowledge, belief, art, morals, laws, customs, and the acquired and shared by the person, as a member of a community, language, aesthetic taste, skills, shared history, traditions, way of life, values and norms." [1]. These are cultural elements that differentiate the lifestyle and interactions between representatives of various ethnic groups. They suggest conflicts that the law should prevent or resolve. For example, in some countries of the Arab world the mass (i.e. committed by many men) molestation or even rape of a female person is a custom known as "Taharrush" [2]. In fact this custom was implemented before in the European Union (Cologne, Zurich, Salzburg and other cities populated by migrants) on the night of 31 December to 1 January $2015 / 16$ by immigrants from the Arab world. The custom is widespread in many Muslim societies inhabiting Africa and Asia; the word "taharrush" means collective flirtation that ends with fornication, robbery or rape of the victim. The centuries-old tradition applies to women who are out alone in public places without wearing the hijab (traditional female garment in the Muslim world) or are dressed indecently according to the norms of Islam. In sharp contrast with the culture of the peoples of Europe, the custom became world famous in 2011 when the journalist Lara Logan was raped while working with her team at Tahrir Square in Cairo, Egypt.

Another example of cultural difference among citizens of European countries and immigrants from Africa and Asia is the status of women in society. According to a French journalist and intellectual Thierry Meyssan, the main dividing line in the Arab world, the cause of many conflicts, are particularly women's rights [3]. Representatives of females are deprived of many fundamental human rights such as the right to vote, to move freely according to their will, to do sports or to drive a car. However, polygamy for men is widespread among most Muslim societies. Such a discriminatory treatment by gender in the rule of law on the European continent is unacceptable.

The above examples embodying cultural differences between different ethnic groups, are a prerequisite for conflicts that the law must prevent or solve. Before that, however, it should be emphasised that the conflict situation is not inspired just by the diversity of cultures. In European countries even before the mass immigration from Asia and Africa, for centuries there had coexisted different ethnicities, organised by a common law order. In Bulgaria, for example, except for the prevailing Bulgarian ethnic group, there are representatives of Roma, Turkish, Armenian and other ethnic groups that are distinguished by their culture, religion and way of life. However, they all live together, organised in a society of a single legal order, whose supreme law is the Constitution, which enjoins through the provision of Art. 6 para. 2 the following: "All citizens are equal before the law. There shall be no restriction of rights or privileges based on race, ethnicity, gender, national origin, religion, education, beliefs, political affiliation, personal or social status or wealth". This provision guarantees the fundamental rights of people regardless the differences between them, all are equal before the law, which organises the society. Thus, guaranteeing basic human rights, the law maintains public homeostasis, overcoming differences between ethnic groups. Despite cultural differences, ethnic groups in Bulgaria, which are organised by the single positive legal order, are characterised by a similar moral system [4], and this is a circumstance which homogenizes them as a society.

It is therefore not just the different culture that is a problem, but the different culture that confronts the cultural characteristics of other ethnic groups (as highlighted by the examples above). A 
problem for the social and legal integration of immigrants from Asia and Africa is their different culture that threatens or harms the fundamental human rights. It is about fundamental individual rights that can not be restricted or deprived because of the female gender or profession of a religion other than Islam. According to various acts of international law on human rights, such as Art. 1 of the Universal Declaration of Human Rights of 1948, "All human beings are born free and equal in dignity and rights." This in turn means "there is a right to equal legal status of persons to goods, objects of legal reality" [5].

The countries immigrants come from and eventually enter Europe are inhabited predominantly by Muslims. The main religion in the Arab world is Islam, and its influence is so strong that it determines even the legal system in the Muslim society. Religion is a cultural element of substantial importance for the Muslim community. It has defined its development for centuries as the main source of law. The Qur'an, the holy book of Muslims, is a foundation for the formation of law [6]. It contains provisions which relate to different spheres of life.

The Qur'an contains rules for armed and unarmed combat to protect Islam (jihad). There are also rules governing family life - family structure, marriage, divorce and inheritance. Next there are the requirements for trade, rent, loan and other contractual relations. Finally, the sacred book of Muslims envisages rules for applying penalties for crimes.

Besides the Qur'an as a second source of Islamic law, the Sunnah is wellknown - the term used to name actions and thoughts of the prophet Mohammed. These actions serve as a model for the interpretation and application of Islamic law.

The sources of law are determined by culture and way of life in a society [7], which is why different societies have different sources of law, and this in turn leads to the formation of different functioning legal systems. The cultural difference between European and Muslim societies therefore determines the effects of different legal systems in these societies the continental legal system in Europe (except for England) and the religious legal system in the Arab world.

The confrontation between different cultural communities is inspired by the need for immigrants to be integrated into the society through the application of the law that is radically different from the one that is the product of their culture in the countries where they come from. Legally, the problem lies in the fact that the cultural peculiarities of Muslim societies have created laws or regulations which find the opposite expression in European legislation (of course, also under the influence of the cultural characteristics of European societies). These are norms of religion and law which contradict the legal norms of European countries. Many of the norms having a forbidding character in the Islamic law are opposed to norms of allowing character in European law and vice versa. For example, European law and the law of individual European countries treats equally men and women with respect for their dignity [8] and fundamental individual rights. The law of Sharia in Muslim countries, however, deprives women of many fundamental rights such as the right to freedom of movement and expression.

In the ascertained cultural and legal differences, which even confront each other, there arises the question of how to integrate immigrants into the local society and legal order.

Prior to the proposed mechanism for social integration, there should be explicitly emphasised that it is not necessary and moreover possible for all the willing people to be accepted as immigrants in Europe. The excessive number of immigrants will create problems in the fields of culture, economy, housing, 
infrastructure and internal order and security, which even law can not solve. So each state, protecting its right of national sovereignty, solely determines how many immigrants (temporarily or permanently) can accept and integrate through its national legislation.

Foreign citizens who are persecuted and are entitled to asylum [9] and those who migrate for other reasons should be integrated into society by means of the existing positive legal order of the state in which they receive asylum. Regardless of the specifics of culture, religion, history and way of life, foreigners must comply with the binding and prohibiting legal norms in the country to which they immigrate. In support of this opinion the following Latin maxim: Prior tempore, potior iure (first in time is first in right) should be highlighted. This is a principle of law which in the continental legal system has proven its usefulness and effectiveness since the time of Ancient Rome. The importance and wisdom of this fundamental principle should be used to avoid confrontation between the existing ethnicities and different culturally numerous immigrants.

The law which organizes society in a democratic rule of law is the product of the will of its people. It is an expression of state sovereignty as an opportunity for each country to independently determine its own internal and foreign policy [10]. And since the problem of social integration of migrants is primarily a matter of domestic policies and the policy is implemented through law making, it follows that the law represents the will of the people, which is the foundation of state formation. Under international law, every country is free solely and independently from other countries to determine the law within its borders against the inhabitants of its ethnic groups. Therefore, those who, for one reason or another, immigrate and join individual countries and the European Community, are required to comply with the existing rule of law, which is to be applied and respected, if not voluntary, then through the state imperium.

Applying the rules of the established positive legal order, the judicial and administrative bodies should treat immigrants in accordance with the established fundamental individual rights in the democratic rule of law. At the same time, the meaning and importance of the legal provisions as they apply to immigrants under the pressure of the term "tolerance" should not be changed. Foreign nationals residing as immigrants in the respective country enjoy the status of the so called "national regime" [11], which includes all the fundamental human rights, with the exception of electoral and other rights that are closely related to citizenship. Immigrants should not receive more rights or be released from the corresponding obligations under the pretext of cultural, religious or any other difference, though many of them are in difficulty. All are equal before the law.

Meanwhile, in order to facilitate the process of social integration, certain legal provisions or regulations should be adopted and/or changed. While developing these new bills, it is important to create conditions for prior public discussions, in which there is a participation by representatives of immigrants and already integrated foreigners by the relevant ethnic group (those, who speak the language of their host country, work and comply with regulatory rules on conduct in the respective community) [12]. In the current information conceptual exchange among local representatives, integrated foreigners and newly arrived immigrants, conflict situations under a generally accepted positive legal order could be resolved. The preliminary regulatory assessment that will arise as a result of such public discussions of draft laws will indicate the conflict zones, will propose ways to overcome them and eventually it is expected to 
contribute to an effectively functioning of the positive legal order.

In times of mass migration and conflict of the culture and customs of various ethnic groups, law is called to realize its main functional purpose maintaining order and preventing conflicts in society. As a social phenomenon that supports public homeostasis, law is a means of integrating immigrants, which should be used by the legislative, judicial and executive power in a contemporary democratic rule of law.

\section{References}

[1] Колев, Т. Правото и правата като културен феномен, С., 2015, с. 7

[2] https://ru.wikipedia.org/wiki/\%D0\%A2\%D0\%B0\%D1\%85\%D0\%B0\%D1\%80\%D1\%80\%D1\%83\%D1\%88

[3] https://alterinformation.wordpress.com/2015/04/04/853249591/

[4] Бойчев, Г. Въведение в правото (Част втора: Философия на правото), С. 2006, 24 - 31

[5] Станин, М., Обекти на правната действителност, Благоевград, 2009 г., с. 26

[6] Колев, Т. История на правораздавателната дейност от Античността до Предмодерната епоха, С., 2010, с. 56 и сл.

[7] Ташев, Р. Обща теория на правото, С., 2010, с. 22

[8] Колев, Т. Правото и правата като културен феномен, С., 2015, 105 - 109

[9] Convention Relating to the Status of Refugees, 28 July, 1951

[10] Белова, Г. Конфликтите - международноправни аспекти, С., 2007, с. 59

[11] Борисов, О. Международно публично право, С., 2013, с. 134

[12] Brinkerhoff, D. and B. Crosby, "Managing Policy Reform" (in Bulgarian), 277 - 279. 